\title{
Impact of nitrogen and sulphur fertilization on the growth and micronutrient content of spring wheat (Triticum aestivum L.)
}

\author{
EVELIN KÁRMEN JUHÁSZ - ANDREA BALLÁNÉ KOVÁCS \\ University of Debrecen, Faculty of Agricultural and Food Sciences and \\ Environmental Management, Institute of Agricultural Chemistry and \\ Soil Science, Debrecen, Hungary \\ evelinjuhasz570@gmail.com
}

\begin{abstract}
Summary
Micronutrients are as important as macronutrients for crops. Each micronutrient has its own function in plant growth. Zinc is important for membrane integrity and phytochrome activities. Copper is an essential micronutrient required for the growth of wheat. Manganese is required for enzyme activation, in electron transport, and in disease resistance. The pot experiment was set up in greenhouse on calcareous chernozem soil Debrecen-Látókép with a spring wheat. In certain development stages (according to $\mathrm{BBCH}$ growth scale of wheat), at the beginning of stem elongation (29-30), at the heading (51-59), at the flowering (61-69) stage three average plants were removed from all pots for analysis. Fresh and dry weight of the plant samples were measured. Plant leaves after drying were digested by $\mathrm{HNO}_{3}-\mathrm{H}_{2} \mathrm{O}_{2}$ methods and manganese, zinc and copper contents of plant were quantified by atomic absorption spectrophotometry. At the flowering stage, when the nutrient uptake of plants is the most intensive, the weight of wheat ranged between $0.94-1.57$ g plant $^{-1}$. In this development stage, the NS2 treatment produced the highest weight of wheat, and compared to this the NS3 treatment decreased that value already. The results show unfavourable effect of NS3 treatment. On the basis of microelement content of wheat and the weight of a plant, nutrient uptake by plant were calculated. At the beginning of growth the starter treatment had positive effect on Cu-uptake compared to the NS1 treatment, where the same dose of fertilizer was stirred into the soil. Wheat is very sensitive to copper deficiency, so copper dissolved by starter treatment could be favourable to the early development of wheat. At flowering stage the Zn-uptake of wheat became the highest and it was between $133.7-234.6 \mathrm{mg}^{\text {plant }}{ }^{-1}$. The Mn-uptake of wheat plant was higher than the $\mathrm{Cu}$ - and $\mathrm{Zn}$-uptake of wheat.

This phenomenon can be explained by the fact that the untreated soil had higher $\mathrm{Mn}$-content, than $\mathrm{Cu}$ - and $\mathrm{Zn}$-content. To summarize the results, it can be stated, that the copper uptake of wheat was more affected by the different treatments in the stage of stem elongation, while $\mathrm{Mn}$ - and $\mathrm{Zn}$-uptake of wheat were influenced primarily in the stage of heading and flowering.
\end{abstract}

Keywords: spring wheat, sulphur, nitrogen, fertilization, yield, nutrient-uptake 


\section{Introduction}

Nitrogen and sulphur are essential for enhancing productivity and quality of wheat. The functions of macronutrients and micronutrients are vital in crop nutrition for improved yield and quality (Saeed et al., 2012).

Micronutrients ( $\mathrm{Zn}, \mathrm{Cu}$ and $\mathrm{Mn})$ are as important as macronutrients $(\mathrm{N}, \mathrm{P}$ and $\mathrm{K})$ for crops. Each micronutrient has own function in plant growth (Asad and Rafique, 2000). Zinc is important for membrane integrity and phytochrome activities (Shkolnik, 1984). Copper is an essential micronutrient required for the growth of wheat (Brown and Clark, 1977).

It is essential for physiological redox processes, pollen viability and lignification (Marschner, 1995). It is essential for photosynthesis and mitochondrial respiration, carbon and nitrogen metabolism, oxidative stress protectioned cell wall synthesis. Manganese is required for enzyme activation, in electron transport, and in disease resistance (Burnell, 1988). In general, the nutrient sufficiency for wheat ranges (for various growth stages) are: Mn 20-150 mg kg-1, Zn 15-70 mg kg-1, Cu 5-25 mg kg-1 (Jones, 1967). Accumulation of macro-and micronutrients in wheat during growth, particularly under $\mathrm{N}$ fertilized conditions, is important and may have implications for crop nutrient management (Hamnér et al., 2017).

The objectives of the experiment were to study the effect of nitrogen and sulphur containing fertilizer on growth and $\mathrm{Zn}-, \mathrm{Cu}-, \mathrm{Mn}$-content of spring wheat at 3 development stages.

\section{Material and methods}

The pot experiment was set up in greenhouse on calcareous chernozem soil Debrecen-Látókép with a spring wheat. Main parameters of experimental soil were $\mathrm{pH}_{\left(\mathrm{CaCl}_{2}\right)}=7.2 ; \mathrm{Hu} \%=2.8 ; \mathrm{K}_{\mathrm{A}}=37.5 ; \mathrm{AL}-\mathrm{P}_{2} \mathrm{O}_{5}=394$ $\mathrm{mg} \mathrm{kg}{ }^{-1} ; \mathrm{AL}-\mathrm{K}_{2} \mathrm{O}=191 \mathrm{mg} \mathrm{kg}^{-1} ; \mathrm{KH}_{2} \mathrm{PO}_{4}-\mathrm{SO}_{4}{ }^{2-}=43.6 \mathrm{mg} \mathrm{kg}^{-1} ; \mathrm{AL}-\mathrm{Ca}=5130$ $\mathrm{mg} \mathrm{kg}{ }^{-1} ; \mathrm{AL}-\mathrm{Mg}=403 \mathrm{mg} \mathrm{kg}^{-1}$; KCl-EDTA-Cu=5.8 mg kg-1; KCl-EDTA$\mathrm{Zn}=7.9 \mathrm{mg} \mathrm{kg}^{-1}$ and $\mathrm{KCl}$-EDTA-Mn=262 $\mathrm{mg} \mathrm{kg}^{-1}$. The soil was properly supplied with $\mathrm{N}$, very well supplied with $\mathrm{P}$ and poorly supplied with $\mathrm{K}$. To establish the experiment, $10 \mathrm{~kg}$ of air dry soil was measured into pots. The moisture content of soils was maintained at $60 \%$ of the water holding capacity of the soil. Pots were weighed daily and lost water was supplemented with ion exchanged water.

The phosphorus and potassium was supplied (as $\mathrm{KH}_{2} \mathrm{PO}_{4}, \mathrm{KCl}$ ) uniformly in all pots. Nitrogen and sulphur were supplied as soil fertilizer by two different ways. One method was when fertilizer was placed next to the seed (starter), while the other way was when fertilizer mixed thoroughly into the soil in increasing doses (NS1, NS2, and NS3). 
The applied soil fertilizer was commercially available fertilizer, YaraBela Sulphan. YaraBela Sulphan fertilizer contains $24 \% \mathrm{~N}$ and $7.2 \%$ S. Five treatments were applied with 3 replications. The treatment plan of the experiment is shown in Table 1.

Table 1. Scheme of the treatments applied

\begin{tabular}{lccccc}
\hline $\begin{array}{c}\text { Number of } \\
\text { treatments }\end{array}$ & $\begin{array}{c}\text { Treatment } \\
\text { label }\end{array}$ & $\begin{array}{c}\text { Fertilizer rate applied in soil } \\
\left(\mathrm{kg} \mathrm{ha}^{-1}\right)\end{array}$ & $\begin{array}{c}\text { Nitrogen rate } \\
\left(\mathrm{g} \mathrm{pot}^{-1}\right)\end{array}$ & $\begin{array}{c}\text { Sulphur rate } \\
\left(\mathrm{kg} \mathrm{ha} \mathrm{ha}^{-1}\right)\end{array}$ \\
\hline 1. & Control & - & - & - & - \\
2. & Starter & 200 & 0.689 & 48 & 12 \\
3. & NS1 & 200 & 0.689 & 48 & 12 \\
4. & NS2 & 400 & 1.379 & 96 & 24 \\
5. & NS3 & 600 & 2.068 & 144 & 36 \\
\hline
\end{tabular}

The dose of NS fertilizer in the 2. and 3. treatments was the same (200 $\mathrm{kg} \mathrm{ha} \mathrm{h}^{-1}$.

40 grains of STANGA spring wheat were sown into all pot and after germination the wheat was thinned to 29 plants per pot, respectively. In certain development stages (according to $\mathrm{BBCH}$ growth scale of wheat), at the beginning of stem elongation (29-30), at the heading (51-59), at the flowering (61-69) stage three average plants were removed from all pots for analysis. Fresh and dry weight of the plant samples were measured.

Plant leaves after drying were digested by $\mathrm{HNO}_{3}-\mathrm{H}_{2} \mathrm{O}_{2}$ methods and manganese, zinc and copper contents of plant were quantified by atomic absorption spectrophotometry.

For statistical analysis of experimental results IBM SPSS Statistics 22 and Microsoft Excel 2016 programs were used. The mean values of each treatment group were subjected to comparisons analysis using the OneWay ANOVA (significance level of $\mathrm{p}<0.05$ ) with post hoc comparisons using Duncan test.

\section{Result and discussion}

The weight of wheat in the stage of stem elongation, heading and flowering The dry weight of wheat in the stage of stem elongation, heading and flowering are shown in Figure 1. According to Figure 1 the weight of wheat at stem elongation ranged between 0.37-0.62 $\mathrm{g}$ plant ${ }^{-1}$. The smallest values were appeared in control and in NS1 treatments while a little higher value was observed in NS3 treatment. Comparing the different treatments it can be stated, that the starter treatment had already beneficial effect on early growing. The increased soil fertilizer doses slightly increased the weight of plant in this stage. 
At the stage of heading the weight of plant varied between $0.84-1.04 \mathrm{~g}$ plant $^{-1}$. In this stage NS3 treatment slightly increased the dry weight of wheat, but this increment was not statistically verifiable.

At the stage of flowering, when the nutrient uptake of plant is the most intensive, the weight of wheat ranged between $0.94-1.57 \mathrm{~g} \mathrm{plant}^{-1}$. Increasing doses of soil fertilizers increased the weight compared to the control treatment, and this was statistically proved. At this stage the starter fertilizer did not cause significant increase any longer. In this development stage, the NS2 treatment produced the highest weight of wheat, and compared to this the NS3 treatment decreased that value already. The results show unfavourable effect of NS3 treatment.

Figure 1. The weight of wheat in the stage of stem elongation, heading and flowering

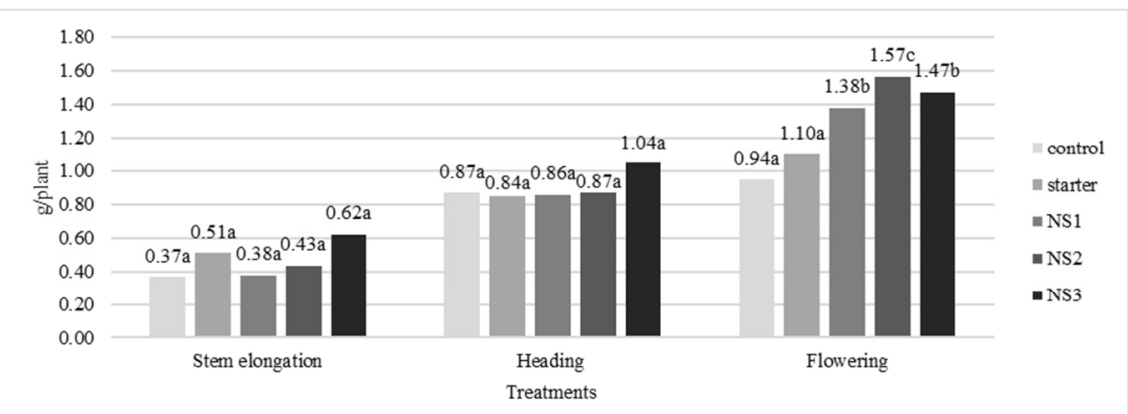

Note: data marked with the same letter is not significantly different at the significant level of $\mathrm{p}<0.05$.

Changes of micronutrient content of plant during the growing season

Changes of $\mathrm{Cu}-, \mathrm{Zn}-, \mathrm{Mn}$-content of plant during the stage of stem elongation, heading and flowering showed in Table 2.

Analysing the changes of copper content of plant during the growing season, it can be concluded, that at stem elongation the Cu-uptake of plant was intensive, and then the Cu-content continuously decreased in time in all treatments. This decrease was also characteristic to other micronutrients as well.

At the stage of stem elongation the $\mathrm{Cu}$-content ranged between 9.90 $11.73 \mathrm{mg} \mathrm{kg}^{-1}$. This is in accordance with the reports of Schwab et al. (2007) where the $\mathrm{Cu}$-content of wheat at stem elongation stage varied between $4.5-15 \mathrm{mg} \mathrm{kg}^{-1}$. The increased doses of fertilizers caused $\mathrm{pH}$ decrease of soil, and this change may cause better solubility and better plant availability of $\mathrm{Cu}$. The treatment with the highest fertilizer dose (NS3) resulted the highest Cu-content of wheat and this was statistically proved. At the stage of heading the $\mathrm{Cu}$-content of plant did not differ in different treatments and ranged between $4.63-5.20 \mathrm{mg} \mathrm{kg}^{-1}$. At the stage 
of flowering the $\mathrm{Cu}$-content of plant decreased and varied between 3.43$4.70 \mathrm{mg} \mathrm{kg}^{-1}$. These results are in good agreement with the finding of Hamnér et al. (2017), who reported that the Cu-content in wheat were less than $10 \mathrm{mg} \mathrm{kg}^{-1}$. The cupper content of plant decreased with increasing of soil fertilizer doses compared to control treatment due to dilution effect.

Table 2. Changes of $\mathrm{Cu}$-, $\mathrm{Zn-}, \mathrm{Mn}$-content of plant during the growing season

\begin{tabular}{|c|c|c|c|}
\hline \multirow{2}{*}{ Treatments } & \multicolumn{3}{|c|}{$\mathrm{Cu}\left(\mathrm{mg} \mathrm{kg}^{-1}\right)$} \\
\hline & Stem elongation & Heading & Flowering \\
\hline Control & $9.90 a$ & $5.20 \mathrm{a}$ & $4.40 \mathrm{a}$ \\
\hline Starter & $10.07 a$ & $4.97 \mathrm{a}$ & $4.70 \mathrm{a}$ \\
\hline NS1 & $10.03 a$ & $4.90 \mathrm{a}$ & $4.07 \mathrm{a}$ \\
\hline NS2 & $10.37 \mathrm{ab}$ & $4.63 a$ & $3.43 \mathrm{a}$ \\
\hline \multirow[t]{2}{*}{ NS3 } & $11.73 b$ & $5.03 a$ & $4.07 \mathrm{a}$ \\
\hline & \multicolumn{3}{|c|}{$\mathrm{Zn}\left(\mathrm{mg} \mathrm{kg}^{-1}\right)$} \\
\hline Control & $32.50 \mathrm{a}$ & $16.10 \mathrm{a}$ & $13.70 \mathrm{a}$ \\
\hline Starter & $28.57 \mathrm{a}$ & $14.50 \mathrm{a}$ & $12.03 a$ \\
\hline NS1 & $30.37 \mathrm{a}$ & $16.13 a$ & $15.10 \mathrm{a}$ \\
\hline NS2 & $38.90 \mathrm{a}$ & $17.20 \mathrm{a}$ & $15.03 a$ \\
\hline \multirow[t]{2}{*}{ NS3 } & $32.93 a$ & $17.23 \mathrm{a}$ & $15.20 \mathrm{a}$ \\
\hline & \multicolumn{3}{|c|}{$\operatorname{Mn}\left(\mathrm{mg} \mathrm{kg}^{-1}\right)$} \\
\hline Control & $58.95 a$ & $31.83 a$ & $25.10 \mathrm{a}$ \\
\hline Starter & $58.70 \mathrm{a}$ & $29.47 \mathrm{a}$ & $23.20 \mathrm{a}$ \\
\hline NS1 & $60.27 a$ & $35.23 a$ & $28.60 \mathrm{a}$ \\
\hline NS2 & $54.27 \mathrm{a}$ & $35.30 \mathrm{a}$ & $24.63 a$ \\
\hline NS3 & $56.57 \mathrm{a}$ & $36.63 a$ & $24.00 \mathrm{a}$ \\
\hline
\end{tabular}

Note: data marked with the same letter in the same columns is not significantly different at the significant level of $\mathrm{p}<0.05$.

Zn concentration in wheat ranged between $28.57-38.9 \mathrm{mg} \mathrm{kg}^{-1}$ at stage of stem elongation. Hamnér et al. (2017) estimated lower values (7.1-28.6 $\mathrm{mg} \mathrm{kg}^{-1}$ ) in his $\mathrm{N}$ fertilization experiment. At this stage of plant, the $\mathrm{Zn}$ content was not influenced by different treatments. At the stage of heading the $\mathrm{Zn}$-content of wheat decreased compared to the previous period, and the values were between $14.50-17.23 \mathrm{mg} \mathrm{kg}^{-1}$. The Zn-content of plant tended to increase with increasing fertilizer doses. Analysing the $\mathrm{Zn}$ values of plant at the stage of flowering it was observed, that the changing tendencies were similar, as in case of the stage of heading.

According the Table 2 the Mn-content ranged between 54.27-60.27 mg $\mathrm{kg}^{-1}$ at stage of stem elongation. The different fertilizer doses did not alter the Mn-content of plant significantly. The NS1 treatment a little bit increased the Mn-content, but the higher dose already reduced these values. Hamnér et al. (2017) came similar conclusions, the Zn-content decreased with increasing $\mathrm{N}$ fertilizer rates. This effect can be observed at the stage of flowering too. 
Changes of the micronutrient uptake by plant during the growing season On the basis of microelement content of wheat and the weight of a plant, nutrient uptake by plant were calculated.

Changes of the $\mathrm{Cu}$-uptake by wheat at the stage of stem elongation, heading and flowering showed in Figure 2. According to Figure 2 the $\mathrm{Cu}-$ uptake of plant varied between $36.4-73.1 \mathrm{mg} \mathrm{plant}^{-1}$ at the stage of stem elongation. At the beginning of growth the starter treatment had positive effect on Cu-uptake compared to the NS1 treatment, where the same dose of fertilizer was stirred into the soil. Wheat is very sensitive to copper deficiency (Korzeniowska, 2008), so copper dissolved by starter treatment could be favourable to the early development of wheat. Increasing fertilizer rates increased the $\mathrm{Cu}$-uptake of wheat plant, but the increment could be statistically proved only by NS3 treatment.

Figure 2. Cu uptake of wheat at different development stage

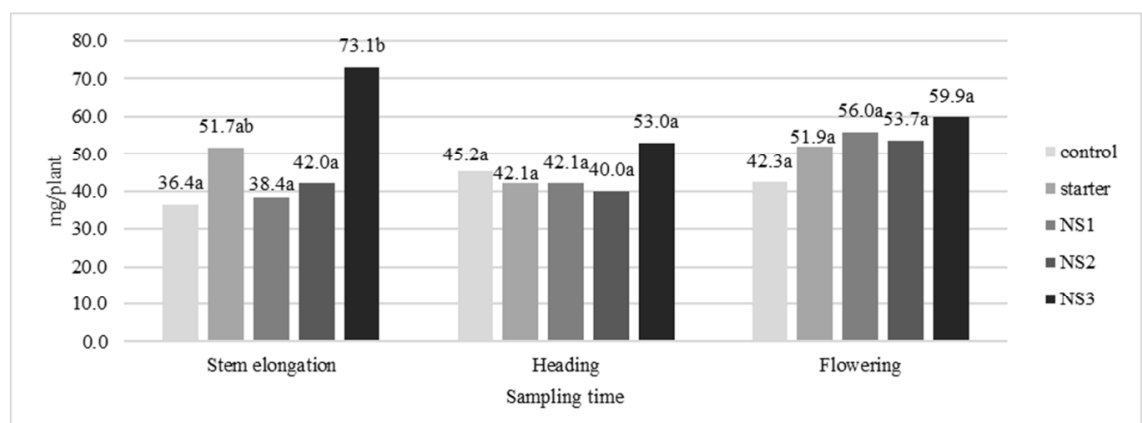

Note: data marked with the same letter is not significantly different at the significant level of $\mathrm{p}<0.05$.

At the stage of heading the treatments had no statistically effect on the Cu-uptake of wheat, although the NS3 treatment resulted slightly increment in copper uptake of plant.

At the third development stage (flowering) the Cu-uptake of plant ranged between $42.3-59.9 \mathrm{mg}$ plant ${ }^{-1}$. All treatments tended to increase the $\mathrm{Cu}$-uptake of wheat, but there was no significant differences between studied values.

The change of the Zn-uptake of wheat at the different stages of development is illustrated in Figure 3. The $\mathrm{Zn}$ values at the stage of stem elongation varied between 115.3-199.3 mg plant ${ }^{-1}$. The starter treatment produced a little bit higher values, than the NS1 treatment with same fertilizer dose. The treatments with increasing fertilizer doses tended to increase the Zn-uptake compared to the control treatment, but this increment was not statistically verifiable. 
At the stage of heading the $\mathrm{Zn}$-uptake of wheat plant ranged between 122.5-180.5 mg plant ${ }^{-1}$. Analysing the effect of the treatments, it can be stated, that there were no any significant effect on the Zn-uptake of plant, only the highest fertilizer dose (NS3) increased slightly the Zn-uptake, because this treatment mobilized more $\mathrm{Zn}$ in soil.

At flowering stage the Zn-uptake of wheat became the highest and it was between 133.7-234.6 mg plant ${ }^{-1}$. In this phase the Zn-uptake of plant already decreased in starter treatment compared to control treatment.

Considering the treatments with increasing NS doses, it can be concluded, that all treatments increased the zinc uptake of plant, but this could be statistically proved only by NS2 treatment.

Figure 3. Zn uptake of wheat at different development stage

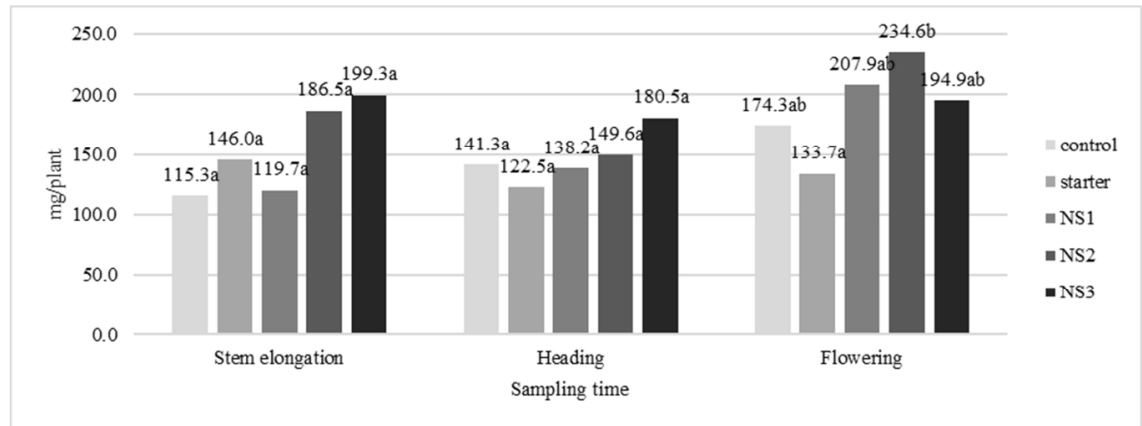

Note: data marked with the same letter is not significantly different at the significant level of $\mathrm{p}<0.05$.

Changes of the Mn-uptake of wheat at the stage of stem elongation, heading and flowering are shown in Figure 4. The Mn-uptake of wheat plant was higher than the $\mathrm{Cu}$ - and $\mathrm{Zn}$-uptake of wheat. This can be explained by the fact that the untreated soil had higher Mn-content, than $\mathrm{Cu}$ - and $\mathrm{Zn}$-content. At the stage of stem elongation the starter treatment repeatedly resulted higher values, than the NS1 treatment. This effect can be observed by $\mathrm{Cu}$ - and Zn-uptake of wheat. Besides that, only NS3 treatment had increasing effect on Mn-uptake of plant.

At the stage of heading the Mn-values ranged between $249.0-383.1 \mathrm{mg}$ plant $^{-1}$. In this stage only NS1 and NS3 treatments increased the Mnuptake of plant in a statistically proven way.

At the stage of flowering the Mn-uptake of wheat varied between 239.5-427.0 mg plant ${ }^{-1}$. The starter treatment had no effect on Mn-uptake of wheat compared to the control treatment, but the Mn-uptake of wheat significantly enhanced by the treatment with same fertilizer dose (NS1). 
The treatments with bigger fertilizer doses considerably increased the $\mathrm{Mn}$ values compared to the control in this stage.

Figure 4. Mn uptake of wheat at different development stage

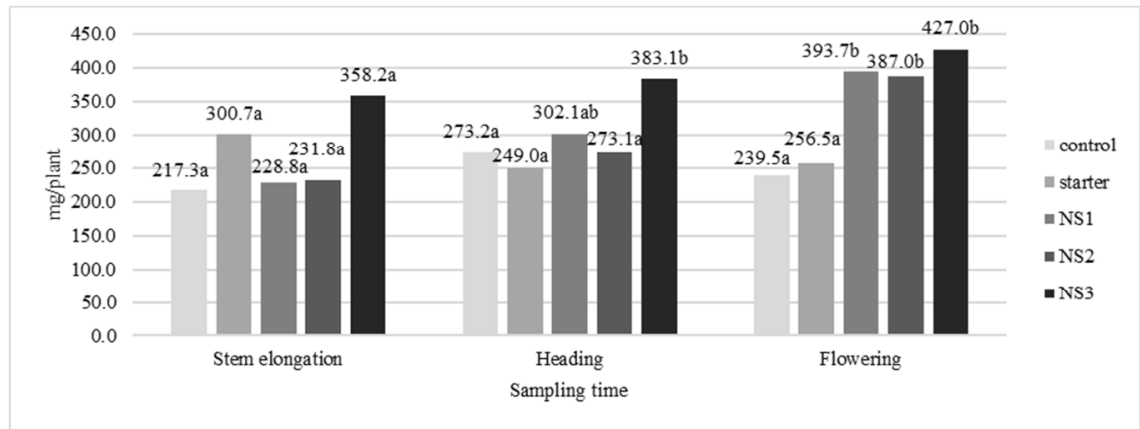

Note: data marked with the same letter is not significantly different at the significant level of $\mathrm{p}<0.05$

\section{Conclusions}

Nitrogen and sulphur containing fertilizers showed to have positive effect on the measured data. The starter treatment had beneficial effect on early growing. In further phases the starter fertilizer did not cause any significant effect on growth. The treatments with increasing fertilizer doses had statistically effect on weight only at stage of flowering.

At the stage of stem elongation the micronutrient uptake of plant was intensive, and then the micronutrient content continuously decreased in time in all treatments. The fertilizers influenced only $\mathrm{Cu}$-content in statistically proved way only at stage of stem elongation.

At the beginning of growth the starter treatment had favourable effect on Cu-uptake compared to the NS1 treatment. Wheat is very sensitive to copper deficiency, so copper dissolved by starter treatment can be favourable to the early development of wheat.

To summarize the results, it can be stated, that the copper uptake of wheat was more affected by the different treatments in the stage of stem elongation, while Mn- and Zn-uptake of wheat were influenced primarily in the stage of heading and flowering.

\section{Acknowledgements}

The publication was supported by the EFOP-3.6.3-VEKOP-16-2017-00008 project and by the project "Establishing a scale-independent complex precision consultancy system" (GINOP-2.2.1-15-2016-0001). The project is co-financed by the European Union and the European Social Fund. 


\section{References}

Asad, A.-Rafique, R. (2000): Effect of Zinc, Copper, Iron, Manganese and Boron on the Yield and Yield Components of Wheat Crop in Tehsil Peshawar, Pakistan Journal of Biological Sciences. 3. 10: 1615-1620.

Brown, J. C.-Clark, R. B. (1977): Copper as essential to wheat reproduction. Plant and Soil. 48: 509-523.

Burnell, J. N. (1988): The Biochemistry of Manganese in Plants. [In: Graham et al. (eds.) Manganese in Soils and Plants.] Kluwer Academic Publisher. Oordracht. 125-137.

Hamnér, K.-Weih, M.-Eriksson, J.-Kirchmann, H. (2017): Influence of nitrogen supply on macro- and micronutrient accumulation during growth of winter wheat. Field Crops Research. 213: 118-129.

Jones, Jr., J. B. (1967): Interpretation of plant analysis for several agronomic crops. [In: Hardy et al. (eds.) Soil testing \& plant analysis: Part II Plant analysis.] SSSA Spec. Publ. No. 2 SSSA. Madison. WI. 49-58.

Korzeniowska, J. (2008): Winter wheat response to copper application under different cultivation technologies and nitrogen fertilization. Ecological chemistry and engineering. 15.1-2: 81.

Marschner, H. (1995): Mineral Nutrition of Higher Plants. Second Edition. Academic Press Ltd. London. UK. 889.

Saeed, B.-Gul, H.-Khan, A. Z.-Badshah, N. L.-Parveen, L.-Khan, A. (2012): Rates and methods of nitrogen and sulphur application influence and cost benefit analysis of wheat. Journal of Agricultural \& Biological Science. 7. 2: 81-85.

Schwab, G. J.-Lee, C. D.-Pearce, R. (2007): Sampling Plant Tissue for Nutrient Analysis. University of Kentucky Cooperative Extension service.

Shkolnik, M. Y. (1984): Trace Elements in Plants. Elsevier. Amsterdam. 